ERRATUM

\title{
Cerebral vasculopathy and strokes in a child with COVID-19 antibodies: \\ illustrative case
}

TO THE READERSHIP: An error appeared in the article by Foster et al. (Foster $\mathrm{CH}$, Vargas AJ, Wells $\mathrm{E}$, et al. Cerebral vasculopathy and strokes in a child with COVID-19 antibodies: illustrative case. J Neurosurg Case Lessons. Published online July 19, 2021. doi:10.3171/ CASE21160).

During production of the article, one co-author's name was changed in error. "Robert F. Foster" is incorrect; the correct name is "Robert F. Keating."

We apologize to the authors for this error. The article has been corrected online as of August 2, 2021.

Gillian Shasby, EMBA

Director of Publications

Journal of Neurosurgery Publishing Group, Charlottesville, VA

INCLUDE WHEN CITING

Published August 2, 2021; DOI: 10.3171/2021.CASE21160a

(c) 2021 The authors, CC BY-NC-ND 4.0 (http://creativecommons.org/licenses/by-nc-nd/4.0/). 